DOE-HTGR-88150

\title{
UNCLASSIFIED
}

Revision 1

\section{STRUCTURAL DESIGN CRITERIA FOR REPLACEABLE GRAPHITE CORE ELEMENTS}

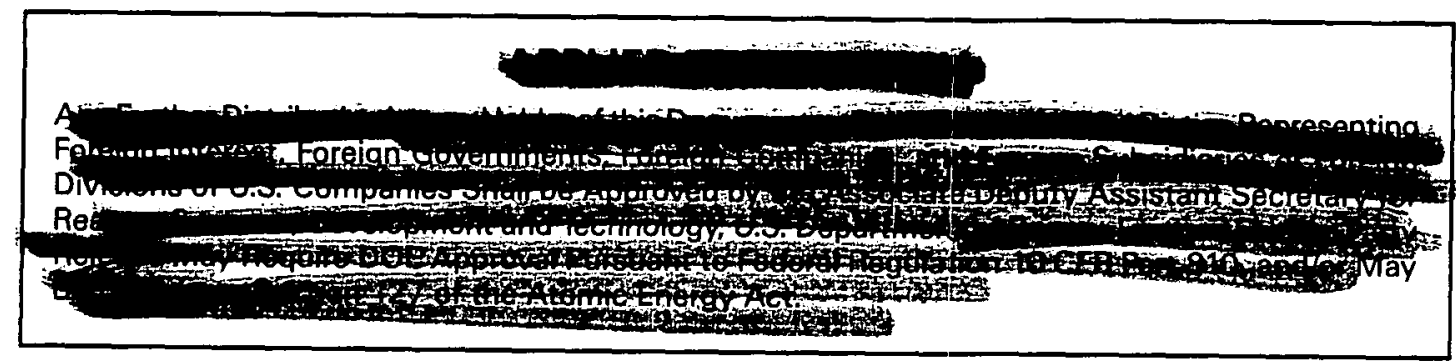

\section{AUTHORS/CONTRACTORS}

\section{GENERAL ATOMICS}

DISTAIBUTION OF THIS DOCUMENT IS LNLIRITES

This tocument is

PUBLICLY RELEASABLE $A . A$.

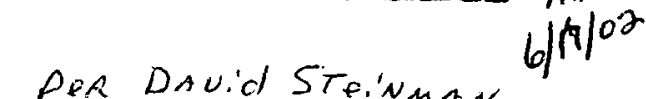

Gereratid STF'NMAN,

Geverat ATOMics, Classir.'CATION

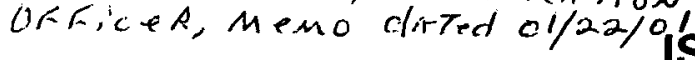

ISSUED BY GENERAL ATOMICS

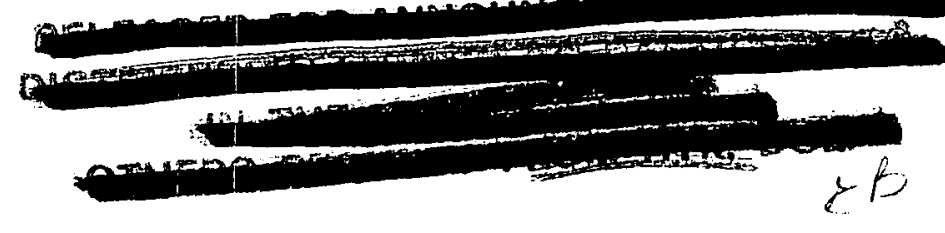

FOR THE DEPARTMENT OF ENERGY

CONTRACT DE-AC03-89SF17885 


\section{DISCLAIMER}

This report was prepared as an account of work sponsored by an agency of the United States Government. Neither the United States Government nor any agency Thereof, nor any of their employees, makes any warranty, express or implied, or assumes any legal liability or responsibility for the accuracy, completeness, or usefulness of any information, apparatus, product, or process disclosed, or represents that its use would not infringe privately owned rights. Reference herein to any specific commercial product, process, or service by trade name, trademark, manufacturer, or otherwise does not necessarily constitute or imply its endorsement, recommendation, or favoring by the United States Government or any agency thereof. The views and opinions of authors expressed herein do not necessarily state or reflect those of the United States Government or any agency thereof. 


\section{DISCLAIMER}

Portions of this document may be illegible in electronic image products. Images are produced from the best available original document. 


\section{UNCLASSIFIED}

\section{CAUTION}

Do not publisly release this document

This technical report is being transmitted in advance of DOE patent clearance and no brther dissemination or publication shall be made of the report without prior approval of the DOE Patent Counsel.

This document willbe returned upon request or when no longer needed, onless notification has been received that this documed has been cleared for release or publication.

STRUCTURAL DESIGN CRITERIA FOR REPLACEABLE GRAPHITE CORE ELEMENTS
DOE-HTGR-88150

Revision 1

\section{PATENT ClEARED \\ $11 / 4 / 91$}

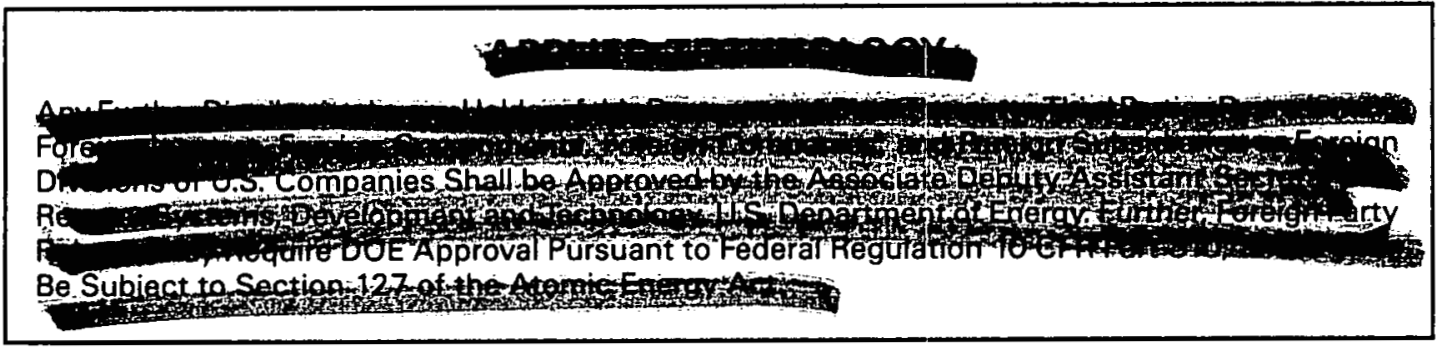

\author{
Issued By: \\ General Atomics \\ P.O. Box 85608 \\ San Diego, California 92138-5608 \\ DOE CONTRACT DE-AC03-89SF17885 \\ GA Project 6300 \\ SEPTEMBER 1989 \\ UNCLASSIFIED
}


RULL 2160 Roll 2208 - rev. 1

ISSUE SUMMARY

\begin{tabular}{|c|c|c|c|}
\hline TITLE & $\begin{array}{l}\text { STRUCTURAL DESIGN CRITERIA FOR } \\
\text { REPLACEABLE GRAPHITE CORE ELEMENTS }\end{array}$ & $\begin{array}{l}\square \text { R\&D } \\
\square \text { OV\& } \\
\text { DESIGN }\end{array}$ & APPROVAL LEVEL \\
\hline
\end{tabular}

\begin{tabular}{|l|l|l|l|l}
\hline DISCIPLINE & SYSTEM & DOC. TYPE & PROJECT & DOCUMENT NO.
\end{tabular} \begin{tabular}{l|l|l|l|l} 
M & 11 & RGE & 6300 & DOE-HTGR-88150 \\
\hline
\end{tabular}

ISSUE NO./LTR.

\begin{tabular}{|l|l|l|l}
\hline QUALITY ASSURANCE LEVEL & SAFETY CLASSIFICATION & SEISMIC CATEGORY
\end{tabular} $\mathrm{N} / \mathrm{A}$

N/A

$\mathrm{N} / \mathrm{A}$

ELECTRICAL CLASSIFICATION

$\mathrm{N} / \mathrm{A}$

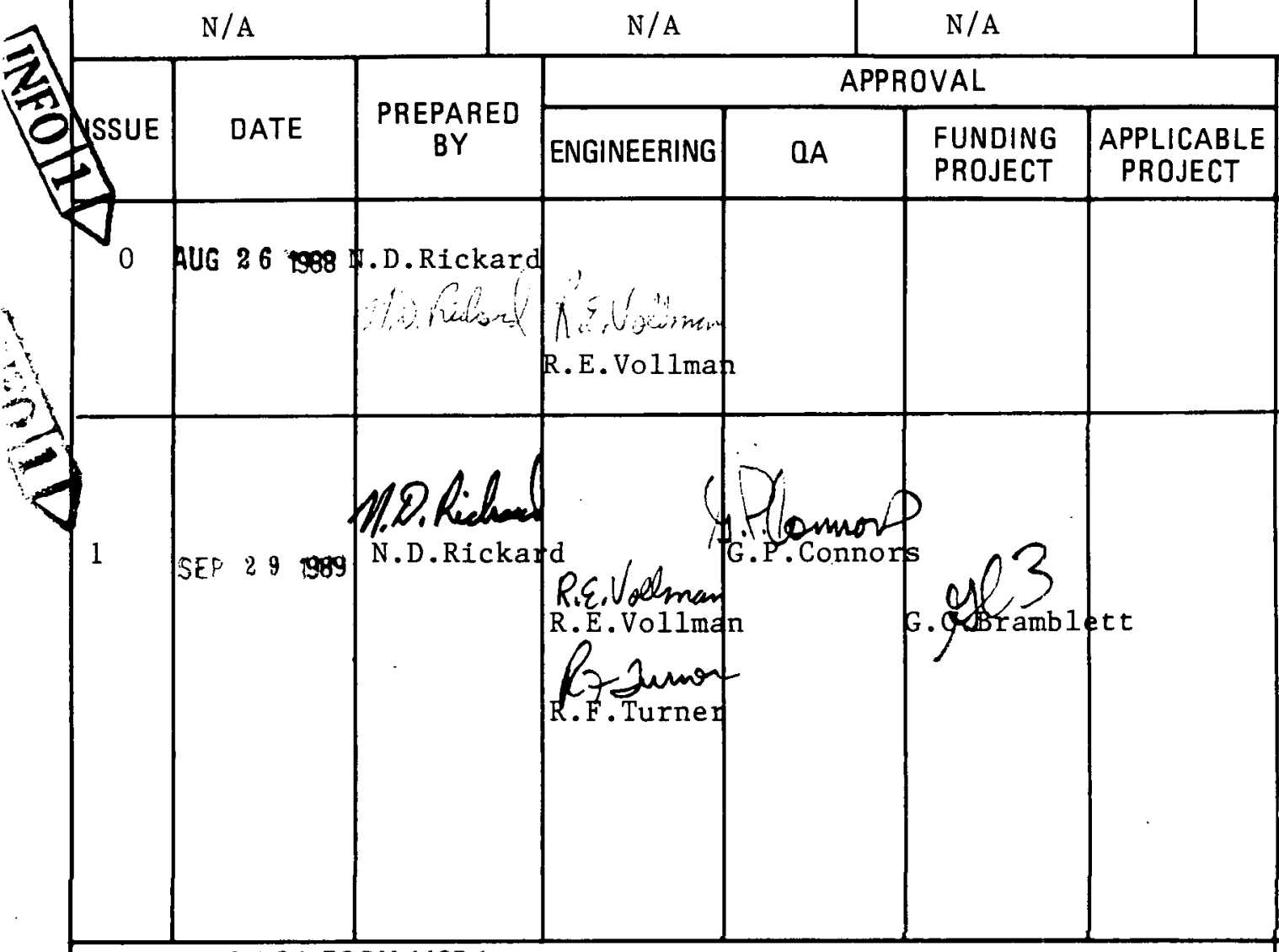

CONTINUE ON GA FORM 1485.1

NEXT INDENTURED DOCUMENTS

*See List of Effective Pages for page count.

Update Criteria

7652115040

SLPP M/S 5211.5 .05

DOE Change Class III

Initial Issue

(909729)

7052115004

SCRIPTION/

CWBS NO.

DOE-HTGR-86035

S senting

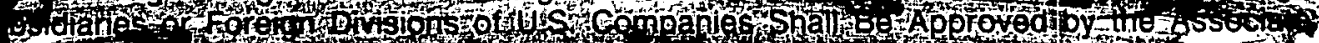

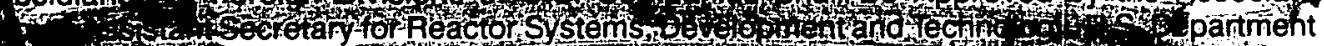

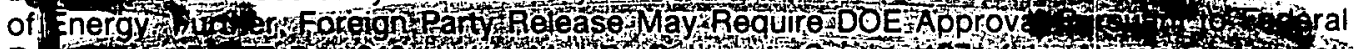

Re

,

GA PROPRIETARY INFORMATION

THIS DOCUMENT IS THE PROPERTY OF GENERAL ATOMICS. ANY TRANSMITTAL OF THIS DOCUMENT OUTSIDE GA WILL BE IN CONFIDENCE. EXCEPT WITH THE WRITTEN CONSENT OF GA, (1) THIS DOCUMENT MAY NOT BE COPIED IN WHOLE OR IN PART AND WILL BE RETURNED UPON REQUEST OR WHEN NO LONGER NEEDED BY RECIPIENT AND (2) INFORMATION CONTAINED HEREIN MAY NOT BE COMMUNICATED TO OTHERS AND MAY BE USED BY RECIPIENT ONLY FOR THE PURPOSE FOR WHICH IT WAS TRANSMITTED. 


\section{LIST OF EFFECTIVE PAGES}

Page Number

i through iv

$1-1$

2-1 through 2-4

3-1 through 3-4

4-1 through 4-2

5-1 through 5-4

6-1

Total Pages
Page Count

4

1

4

4

2

4

1

20
Revision

1

1

1

1

1

1

1 
CONTENTS

1. INTRODUCTION . . . . . . . . . . . . . . . . . . . 1-1

1.1. Scope ....................... . 1-1

1.2. Applicability . . . . . . . . . . . . . . 1-1

2. GENERAL DESIGN CRITERIA . . . . . . . . . . . . . . . 2-1

2.1. Loading Criteria . . . . . . . . . . . . . 2-1

2.2. Material Properties . . . . . . . . . . . 2-3

2.3. Special Considerations. . . . . . . . . . . . 2-3

2.3.1. Corrosion................. 2-3

2.3.2. Fracture Mechanics .... . . . . . . 2-4

3.DESIGN BY ANALYSIS. . . . . . . . . . . . . . . . . . . 3-1

3.1. Method of Analysis. . . . . . . . . . . . . . 3-1

3.2. Analysis Input Data . . . . . . . . . . . . . 3-2

3.3. Calculations of Strength . . . . . . . . . . . . 3-2

4. DESIGN BY TEST AND ANALYSIS . . . . . . . . . . . . . . . 4-1

4.1. Design by Test. . . . . . . . . . . . . . . 4-1

4.2. Design by Combined Test and Analysis. . . . . . . . 4-1

5. STRESS LIMITS . . . . . . . . . . . . . . . 5-1

5.1. Fuel and Reflector Element Stress Limits . . . . . . 5-1

5.2. Dowe1/Dowe1-Socket Stress Limits. . . . . . . . . . 5-1

5.3. Fatigue Stress Limits... . . . . . . . . . . 5-2

6. REFERENCES . . . . . . . . . . . . . . . . 6-1

TABLES

1. Fuel and Reflector Element stress limits . . . . . . . . . 5-3

2. Dowe1/dowe1-socket stress 11mits . . . . . . . . . . . 5-4 


\section{INTRODUCTION}

\subsection{SCOPE}

This document describes the structural criteria for the design of the replaceable graphite elements of the Modular High Temperature GasCooled Reactor (MHTGR) core.

\subsection{APPLICABILITY}

These criteria are applicable to the design of the MHTGR fuel elements and replaceable reflector elements and are applicable only for the reactor configuration defined by the Reactor System Design Description (Ref. 1). 


\section{GENERAL DESIGN CRITERIA}

The design of graphite elements governed by these criteria shall account for the brittle behavior of graphite, the low tensile strength relative to compressive strength, the effects of neutron irradiation and temperature in material behavior, and the process by which the graphite was manufactured. Failure due to stress shall be governed by the maximum principal stress theory commonly used for brittle materials.

The core graphite elements shall be designed by analysis or by a combination of test and analysis. Due to the wide range of possible thermal/irradiation loading conditions and the difficulty associated with simulating these conditions by test, design by analysis is required for thermal/irradiation loads. However, for mechanical loads such as seismic loads, it may be advantageous to verify the design by a combination of analysis and test results. The rules for design by analysis are presented in Section 3. The rules for design by test and analysis are presented in Section 4.

\subsection{LOADING CRITERIA}

Loads on MHTGR core graphite components are of three types: (1) mechanical, (2) differential thermal strains, and (3) differential irradiation induced dimensional change and shall be accounted for in the design. 
Representative loads include but are not limited to the following:

- Core pressure drop from primary coolant flow

- Dead weight

- Weight of fuel pins

- Weight of shield structures

- Fuel handling motion

- Seismic motion from both the Operational Basis Earthquake (OBE) and the Safe Shutdown Earthquake (SSE)

- Flow induced vibration

- Acoustic vibrations

- Time dependent irradiation induced dimensional change caused by neutrons fluence

- Steady state temperature differences

- Transient temperature changes resulting from primary coolant flow

- Plant operational load change transients

- Scram transients

- Postulated accident conditions such as loss of coolant flow followed by a conduction cooldown 
Specific loading conditions for each component shall be obtained from the appropriate component design specification. The loading conditions shall be assigned to service levels $A, B, C$, or $D$ as prescribed in the appropriate component design specification.

The initial conditions considered for each event shall include any conditions that could exist at the time of the event assuming (1) the prior occurrence of any or all of the Service Level A or B events, and (2) the concurrent occurrence of any Service Level A event. The design shall be shown to withstand the load conditions and combinations thereof specified in the Core Component Design Specification (Ref, 5).

\subsection{MATERIAL PROPERTIES}

Mean values of material behavior data and failure data shall be used to show compliance with theses criteria. Statistically significant quantities of data shall be used to know these mean values at a confidence level of $95 \%$. The variability within a billet, from billet to billet, and from lot to lot shall be included in the statistical evaluation of material property data. The material property behavior to be used in evaluation of components to these criterfa shall be obtained from the Graphite Design Handbook (Ref. 2).

\subsection{SPECIAL CONSIDERATIONS}

\subsubsection{Corrosion}

The effects of environmentally caused degradation shall be accounted for in the design. In particular the effects on material behavior and fallure stress of graphite corrosion caused by moisture, carbon monoxide, and carbon dioxide shall be included in the design evaluations such that these criteria are met for the extremes of these effects. 


\subsubsection{Fracture Mechanics}

When fracture mechanics principles are used to evaluate crack propagation the assumed initial flaw size shall be greater than the minimum that can be detected by NDE and/or implied by proof testing of the components. 


\section{DESIGN BY ANALYSIS}

The following rules shall be used for design by analysis.

\subsection{METHOD OF ANALYSIS}

The time dependent strains induced by temperature, stress, and neutron irradiation shall be calculated in the stress analysis. These strains shall include thermal, irradiation, elastic, transient creep, and steady creep strains. The analysis shall include the effects of temperature on material properties, Irradiation on material properties, the anisotropy of the material, and the systematic spatial variations of the graphite strength. In addition, the graphite strength shall be adjusted for grain size effects and volume effects as described in Section 3.3 .

The design shall allow crack initiation and limited crack propagation for certain specifled low frequency events as specified in Section 5.1. The extent of crack propagation shall be evaluated by performing a series of finite-element analyses in which the maximum stressed finite element is analytically cut and the analysis repeated until (1) the maximum stress is reduced below the maximum allowable stress, and (2) the crack terminates at an element surface (e.g., a fuel hole or coolant hole). To reduce the number of finite-element analyses cases when modeling crack propagation, several finite elements may be cut between each iteration. The crack shall not (1) cause a piece to separate from the element or (2) exceed the design limits for crack opening or crack length. 


\subsection{ANALYSIS INPUT DATA}

The input used in the analysis shall be as follows:

1. Material Properties. Mean values of the materlal properties (e.g., Young's Modulus, irradiation creep moduli, thermal conductivity, etc.) shall be used in the analysis.

2. Dimensions. The analysis shall use nominal dimensions reduced to reflect the maximum removal of material due to graphite corrosion that would be expected to exist at the time of the event being analyzed (see Section 2.3.1).

\subsection{CALCULATION OF STRENGTH}

The maximum principal strength theory of failure shall be used in conjunction with the Weibull weakest link theory to account for volume effects on strength.

The systematic spatial variations of the graphite strength shall be accounted for as described in the Graphite Design Handbook (Section 4.5.3) of Ref. 2). In addition, the following equation (Ref. 3) shall be used to adjust the strength at a point in the graphite for volume and grain size effects:

$$
\mathrm{SSR}=\mathrm{SSR}_{\mathrm{S}} \frac{\mathrm{F}_{0}}{\mathrm{~F}_{1}} \quad \frac{\mathrm{V}_{1}}{\mathrm{~V}_{0}}{ }^{1 / \mathrm{m}}
$$

where $\quad$ SSR = ratio of principal stress to mean graphite strength at a point adjusted for spatial, grain size, and volume effects, 


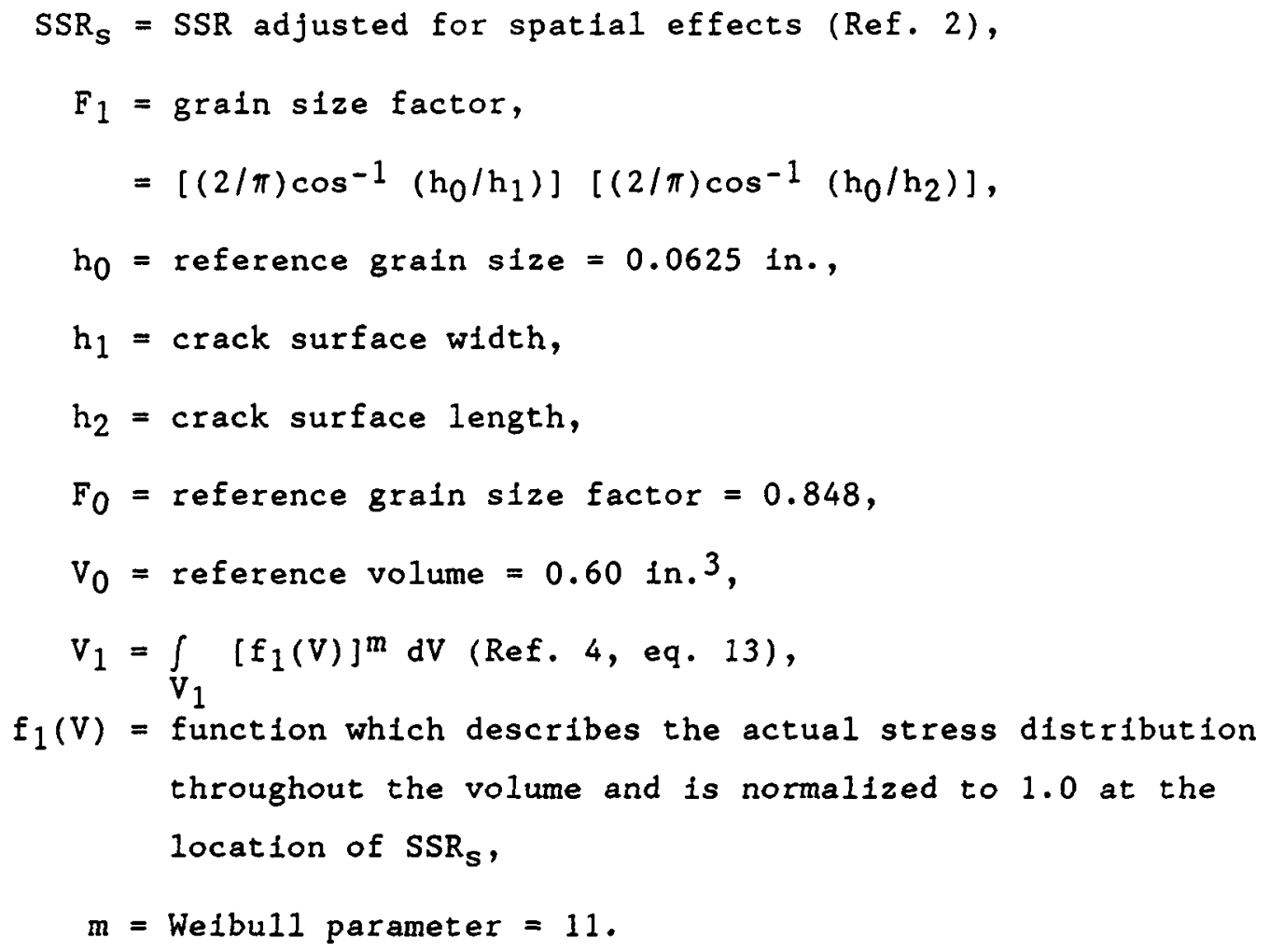

The following rules govern the computation of $v_{1}$ :

1. In general, $V_{1}$ shall be evaluated for a single finite element.

2. Additional finite elements shall be included in the evaluation of $v_{1}$ if including these elements could cause the adjusted SSR to exceed the design limits.

3. The volume shall only include material that is subjected to tensile principal stresses. For example, in a finite element that is subjected to pure bending, only the half subjected to tension shall be included in the volume.

4. The function $f_{I}(V)$ can conservatively be assumed to be equal to 1.0 providing that $S_{S}$ is the maximum $S_{S}$ in the volume. 
5. The maximum $\mathrm{SSR}_{S}$ in a volume may be approximated by the maximum $\mathrm{SSR}_{S}$ evaluated at the finite-element integration points.

The following rules govern the selection of $h_{1}$ and $h_{2}$ for the computation of $F_{1}$ :

1. In general, $h_{1}$ and $h_{2}$ shall be the dimensions of the potential failure surface assuming the complete ultimate failure of the surface (i.e., not just crack initiation, but crack propagation across the entire surface). For the example of a fuel element web, $h_{1}$ is the thickness of the web, and $h_{2}$ is the height of the fuel element.

2. The potential failure surface shall pass through the volume that is being evaluated.

3. The dimensions of the potential failure surface ( $h_{1}$ and $h_{2}$ ) shall not include any previously cracked material. For example in a crack propagation analysis, $h_{1}$ and $h_{2}$ shall be the dimensions of the uncracked surface. Therefore, as the crack propagates, the area of the potential fallure surface will become smaller. 


\section{DESIGN BY TEST AND ANALYSIS}

Design by a combination of test and analysis is permitted for load combinations which have a maximum SSR $<0.60$ since (1) a crackpropagation analysis is required if the maximum SSR is $>0.60$ and (2) the design-by-test methodology is not applicable to crack-propagation analysis.

\subsection{DESIGN-BY-TEST}

A series of tests shall be conducted which measure the load required to initiate a crack. This load shall be designated the ultimate load. From these data, the mean and minimum ultimate loads shall be computed. The minimum ultimate load shall be the load that has $99 \%$ probability with $95 \%$ confidence that crack initiation will not occur.

The design-by-test SSR shall be computed as follows:

$$
\text { SSR }=(\text { Applied Load }) /(\text { Allowable Ultimate Load }) \text {. }
$$

where the "allowable ultimate load" is the smaller of the mean ultimate load or $1.45 \times$ (minimum ultimate load).

\subsection{DESIGN BY COMBINED TEST AND ANALYSIS}

The combined design-by-test-and-analysis SSR shall be computed by arithmetically adding the design-by-test SSR to the maximum design-byanalysis SSR without regard to the direction or location of the maximum stress. The combination of SSRs results in an upper bound to the actual SSR at a particular point. The combined upper bound SSR shall be less than or equal to the design limits of Section 5.1. 
The design engineer may use other methods to combine the design-bytest and design-by-analysis results provided that an upper bound to the combined SSR is obtained. It shall be the responsibly of the design engineer to demonstrate that the resulting SSR is an upper bound to the maximum combined SSR. 


\section{STRESS LIMITS}

The design of replaceable graphite elements in the core shall be such that the princlpal stress values, when expressed as stress-to-strength ratios (SSRs), will not exceed the stress limits of this section.

Stress-to-strength-ratio (SSR) is defined as the ratio of the principal stress to mean graphite strength.

\subsection{FUEL AND REFLECTOR ELEMENT STRESS LIMITS}

The graphite stress limits presented in Table 1 shall apply to stresses produced by all load combinations except load combinations which include loads acting on or reacted by the dowels (see Section 5.2). The design limits for Service Level $A$ and $B$ events must be met without allowing the element to crack. For Service Level $C$ and $D$ events, crack initiation and limited crack propagation are allowed. The crack-opening design limits only apply to fuel elements. Non-fuel elements shall meet the SSR design limits and the crack-length design limits.

\subsection{DOWEL/DOWEL-SOCKET STRESS LIMITS}

The dowel/dowel-socket stress limits presented in Table 2 shall apply to stresses produced by or partially produced by loads acting on the dowels or reacted by the dowels. SSRs shall be computed using the methodology described in Sections 3 and 4. Crack-propagation analysis is not permitted. 
5.3. FATIGUE STRESS LIMITS

(To be included later) 
TABLE 1

FUEL AND REFLECTOR ELEMENT STRESS LIMITS

\begin{tabular}{clcc}
\hline Service Level & SSR & $\begin{array}{c}\text { Crack Length } \\
\text { (in.) }\end{array}$ & $\begin{array}{c}\text { Crack Opening(a) } \\
\text { (in.) }\end{array}$ \\
\hline A & 0.5 & (b) & (b) \\
B & 0.6 & (b) & (b) \\
C & 0.6 & $7.0($ c) & 0.020 \\
D & 0.6 & (d) & 0.025 \\
\hline
\end{tabular}

(a) The design limits for crack opening apply only to fuel elements. Reflector elements are limited by notes (c) and (d) below.

(b) Crack initiation is not permitted.

(c) The sum of the lengths of all cracks in an element shall not exceed 7.0 in., and the element shall remain in one piece.

(d) The element shall remain in one piece. 
TABLE 2

DOWEL / DOWEL - SOCKET

STRESS

\begin{tabular}{cc}
\hline Service Level & SSR \\
\hline A & 0.45 \\
B & 0.45 \\
C & 0.55 \\
D & 0.60
\end{tabular}




\section{REFERENCES}

1. "Reactor System Design Description," GA Document DOE-HTGR-86035, Rev. 2, Apri1 1988.

2. Ho, F. H., "Graphite Design Handbook," GA Document DOE-HTGR-88111, Rev. 0, September 1988.

3. Ho, F. H., "A Modified Weibull Theory for the Strength of Granular Brittle Material," GA Report GA-A15228, May 1979.

4. Robinson, E. Y., "The Statistical Nature of Fracture," UCRL-50622, TID-4500, UC-25, Lawrence Radiation Laboratory, University of California, 1969.

5. "Core Component Design Specification," GA Document DOE-HTGR-88134, Rev. 0, October 1988 .

6. "Overall Plant Design Specification Modular High Temperature GasCooled Reactor," GA Document DOE-HTGR-86004, Rev. 7, August 1988. 